\title{
BIOCHEMICAL PROPERTIES OF THE NERVE GROWTH FACTOR-INDUCIBLE LARGE EXTERNAL (NILE) GLYCOPROTEIN ${ }^{1}$
}

\author{
STEPHEN R. J. SALTON, MICHAEL L. SHELANSKI, and LLOYD A. GREENE ${ }^{2}$ \\ Department of Pharmacology, New York University School of Medicine, New York, New York 10016
}

Received February 4, 1983; Revised June 6, 1983; Accepted June 8, 1983

\begin{abstract}
In the presence of nerve growth factor (NGF), PC12 pheochromocytoma cells undergo neuronal differentiation with a concomitant 3- to 5-fold increase in the specific level of an $M_{\mathrm{r}}=230,000$ cell surface component named the NGF-inducible large external, or NILE, glycoprotein. Antisera raised against NILE glycoprotein (NILE GP) purified from PC12 cells have been found to recognize most, if not all, neurons derived from the peripheral and central nervous systems. In the current studies several of the biochemical properties of NILE GP were investigated. NILE GP was found to be phosphorylated in NGF-treated and -untreated PC12 cells and in cultured rat sympathetic neurons. The phosphate moiety of NILE GP is almost completely alkali labile, suggesting that phosphoserine groups predominate. Immunoprecipitation experiments revealed that incorporation of $\left[{ }^{32} \mathrm{P}\right] \mathrm{phos}-$ phate into NILE GP relative to total PC12 cell phosphoprotein was not significantly altered at 12 and $24 \mathrm{hr}$ of NGF treatment but was enhanced 3 -fold after 7 days and up to 5 -fold after 2 to 3 weeks of NGF exposure. These changes in phosphorylated NILE GP paralleled, and therefore appeared to be mainly a consequence of, the NGF-induced increase in total cellular levels of NILE GP. By two-dimensional gel analysis, anti-NILE GP selectively immunoprecipitated two NGFinducible spots (apparent $M_{\mathrm{r}}=230,000 ; \mathrm{pI}=6.4$ to 6.6) from PC12 cells labeled with either $\left.{ }^{3} \mathrm{H}\right]$ fucose, $\left[{ }^{35} \mathrm{~S}\right]$ methionine, or $\left[{ }^{32} \mathrm{P}\right]$ phosphate. Anti-NILE GP immunoprecipitated a single band (apparent $M_{\mathrm{r}}=205,000$ ) from extracts of rat brain labeled with $\left[{ }^{3} \mathrm{H}\right]$ glucosamine. This confirms the previously established apparent molecular weight difference between central and peripheral NILE GP cross-reactive material. When PC12 cells, cerebellar cultures, and cultured cerebral cortex were treated with tunicamycin and labeled with $\left.{ }^{35} \mathrm{~S}\right]$ methionine, nonglycosylated bands each with $M_{\mathrm{r}}=160,000$ were immunoprecipitated, implying that the differences in the mobilities on sodium dodecyl sulfate gels of cross-reactive NILE GP from different tissues is due to variation in glycosylation rather than to large differences in apoprotein structure. Prolonged treatment of PC12 cells with trypsin produced an immunoreactive fragment of NILE GP of apparent $M_{\mathrm{r}}=28,000$ that was phosphorylated but not glycosylated, and that remained in the membrane. NILE GP remained predominantly membrane associated under a variety of aqueous extraction conditions, suggesting that it is an integral membrane protein.
\end{abstract}

Cell surface macromolecules are thought to play an important role in the development and maturation of the nervous system (Sidman, 1974; Barondes and Rosen, 1976; Moscona, 1976; McClain and Edelman, 1982). Antibodies directed against surface markers have been used

\footnotetext{
${ }^{1}$ This research was supported by United States Public Health Service Grants NS16036 and NS16839. S. R. J. S. is a Medical Scientist Training Program Fellow (GM07308). We thank Dr. R. Margolis for aid in the in situ labeling of rat brains.

${ }^{2}$ To whom correspondence should be addressed, at Department of Pharmacology, New York University Medical Center, 550 First Avenue, New York, NY 10016.
}

to study the interaction of defined subpopulations of neural cells during development (cf. McKay et al., 1981). Surface components unique to neural cells, some of which are modulated during neuronal morphogenesis, have been examined in clonal cell lines and primary neuronal cultures (cf. Akeson and Hsu, 1978; Littauer et al., 1980; Rohrer and Schachner, 1980; Lee et al., 1981; Salton et al., 1983).

The PC12 pheochromocytoma cell line, in particular, has been widely employed in the study of neuronal differentiation (Greene and Tischler, 1976). PC12 cells synthesize, store, and release catecholamines (Greene and Rein, 1977, 1978), and contain chromaffin granules 
(Greene and Tischler, 1976), as do normal adrenal chromaffin cells. Addition of nerve growth factor (NGF) causes PC12 cells to cease mitosis and acquire a number of morphological, physiological, and biochemical properties associated with sympathetic neurons (Greene and Tischler, 1976, 1982). Alterations of PC12 cell composition which accompany NGF-triggered neuronal differentiation are therefore of considerable interest. Comparison of the total cell proteins synthesized by PC12 cells before and after NGF treatment reveals only a few compositional changes (McGuire et al., 1978; Garrels and Schubert, 1979; Fuji et al., 1982). Among these is a marked induction in the incorporation of radiolabeled fucose or glucosamine into a glycoprotein of apparent $M_{\mathrm{r}}$ $=230,000$ (McGuire et al., 1978). This change has more recently been determined to reflect a 3 - to 5 -fold increase in the specific level of this macromolecule (Salton et al., 1983). In intact PC12 cells, this component can be removed by trypsin or labeled by lactoperoxidase-catalyzed iodination, suggesting that it is present on the cell surface (McGuire et al., 1978; Lee et al., 1981). On the basis of these properties, this macromolecule was named the NGF-inducible large external, or NILE, glycoprotein.

NILE glycoprotein (NILE GP) has been isolated from PC12 cells by wheat germ agglutinin-agarose affinity chromatography and sodium dodecyl sulfate-polyacrylamide gel electrophoresis (SDS-PAGE) (Salton et al., 1983). Antisera raised against purified NILE GP (antiNILE GP) selectively recognize a 230,000-dalton glycoprotein in extracts of $\mathrm{PC} 12$ cells labeled with $\left[{ }^{3} \mathrm{H}\right]$ fucose, $\left[{ }^{3} \mathrm{H}\right]$ glucosamine or $\left[{ }^{35} \mathrm{~S}\right]$ methionine, and stain the surfaces of PC12 cells by indirect immunofluorescence (Salton et al., 1983). Immunofluorescent staining of tissue whole mounts and primary cultures revealed that a crossreactive NILE GP species is present on the surfaces of most, if not all, central and peripheral neurons examined, to a small extent on the surfaces of Schwann cells, and not at all on a wide variety of other cell types. Immunoprecipitation of radiolabeled cultures showed that the cross-reactive material had an apparent $M_{\mathrm{r}}$ by SDSPAGE of 225,000 to 230,000 , in the peripheral nervous system (PNS) and 200,000 to 210,000 in the central nervous system (CNS) (Lee et al., 1981; Salton et al., 1983; Stallcup et al., 1983). The current work explores several macromolecular properties of central and peripheral immunologically cross-reactive NILE GP.

\section{Experimental Procedures}

Cell culture. PC12 cells were grown by previously published methods (Greene and Tischler, 1976) in complete medium (85\% RPMI 1640, 10\% horse serum, and 5\% fetal calf serum; KC Biologicals, Inc.) with or without 50 $\mathrm{ng} / \mathrm{ml}$ of $2.5 \mathrm{~S}$ NGF (Mobley et al., 1976). Dissociated cultures of rat postnatal superior cervical sympathetic ganglion and cerebellum and embryonic cerebral cortex were prepared as previously described (Hatten, 1981; Salton et al., 1983). All cells were grown in a humidified atmosphere of $93 \%$ air $/ 7 \% \mathrm{CO}_{2}$ at $37^{\circ} \mathrm{C}$.

Labeling of cells. Glycoproteins were labeled by incubating cells for $72 \mathrm{hr}$ in complete medium supplemented with 20 to $30 \mu \mathrm{Ci} / \mathrm{ml}$ of either $\mathrm{L}-\left[5,6-{ }^{3} \mathrm{H}\right]$ fucose $(56.0 \mathrm{Ci} /$ mmol; New England Nuclear) or D- $\left[6-{ }^{3} \mathrm{H}\right]$ glucosamine hydrochloride (22.6 Ci/mmol; Amersham). Cells to be labeled with $\mathrm{L}-\left[{ }^{35} \mathrm{~S}\right]$ methionine were preincubated for 2.5 $\mathrm{hr}$ in methionine-deficient, serum-free medium, followed by a 4 - to 5 -hr incubation in the same medium containing $100 \mu \mathrm{Ci} / \mathrm{ml}$ of $\mathrm{L}-\left[{ }^{35} \mathrm{~S}\right]$ methionine $(1200 \mathrm{Ci} / \mathrm{mmol}$; New England Nuclear). In certain studies, 2 to $5 \mu \mathrm{g} / \mathrm{ml}$ of tunicamycin (Calbiochem, Lot No. 002689) were included in the preincubation and labeling media. PC12 cells were labeled with $100 \mu \mathrm{Ci} / \mathrm{ml}$ of $\left[{ }^{32} \mathrm{P}\right]$ dipotassium phosphate (50 to $1000 \mathrm{mCi} / \mathrm{mmol}$; New England Nuclear) in phosphate-free, HEPES-buffered, modified Krebs-Ringers saline (Greene and Rein, 1977) for 2 to 3 $\mathrm{hr}$ at $37^{\circ} \mathrm{C}$. NGF-treated cultures were labeled in this medium supplemented with $50 \mathrm{ng} / \mathrm{ml}$ of NGF. Radiolabeling of cultures was terminated by three rinses with phosphate-buffered saline (PBS; Dulbecco and Vogt, 1954), followed by addition of $1 \%$ SDS and boiling.

Rat brains were radiolabeled in situ by intracerebral injection of 30-day-old rats (Sprague-Dawley) with 0.83 $\mathrm{mCi}$ of $\left[{ }^{3} \mathrm{H}\right]$ glucosamine hydrochloride in $15 \mu \mathrm{l}$ of saline. After $18 \mathrm{hr}$, rats were sacrificed, and their brains were removed and each solubilized in $10 \mathrm{ml}$ of Buffer A (see immunoprecipitation below) using a Polytron. The extract was centrifuged at $180,000 \times g$ for $2 \mathrm{hr}$, and aliquots of the supernatant were analyzed by immunoprecipitation.

Trypsinization. PC12 cells were incubated in HEPESbuffered modified Krebs-Ringers saline containing 100 $\mu \mathrm{Ci} / \mathrm{ml}$ of $\left[{ }^{32} \mathrm{P}\right]$ phosphate and $100 \mu \mathrm{g} / \mathrm{ml}$ of trypsin (Worthington Biochemical Corp.; 221 units $/ \mathrm{mg}$ ) for $3 \mathrm{hr}$ at $37^{\circ} \mathrm{C}$. Crude phosphorylated membranes were isolated by three rapid cycles of freezing and thawing in $5 \mathrm{~mm}$ Tris$\mathrm{HCl}(\mathrm{pH} 8.0$ ) containing $20 \mathrm{~mm}$ sodium molybdate (End et al., 1982), $20 \mathrm{~mm}$ sodium fluoride, and $20 \mathrm{mM}$ nitrilotriacetic acid (Linne and Philipson, 1980) as phosphatase inhibitors, followed by centrifugation at $15,000 \mathrm{rpm}$ in a Brinkmann Microfuge for $15 \mathrm{~min}$ at $4^{\circ} \mathrm{C}$. Crude membrane fractions were then extracted with $1 \%$ SDS and boiled. PC12 cells metabolically labeled with $\left[{ }^{3} \mathrm{H}\right]$ fucose were treated with trypsin as previously described (Lee et al., 1981; Salton et al., 1983).

Preparation of antisera and immunoprecipitation. Antisera were raised against purified NILE GP as previously described (Salton et al., 1983). For immunoprecipitation, labeled cells were extracted in $1 \%$ SDS, diluted 1:5 with Buffer A (2.5\% Triton X-100, $190 \mathrm{~mm}$ $\mathrm{NaCl}, 50 \mathrm{~mm}$ Tris- $\mathrm{HCl}, 6 \mathrm{~mm}$ EDTA, $2 \mathrm{~mm}$ phenylmethylsulfonyl fluoride, $100 \mathrm{units} / \mathrm{ml}$ of aprotinin, $\mathrm{pH} 8.0$ ), and then centrifuged at $143,000 \times g$ for $1 \mathrm{hr}$ at $4^{\circ} \mathrm{C}$. Indirect immunoprecipitation, using protein A-Sepharose (Pharmacia), was carried out by minor modification (Salton et al., 1983) of published procedures (Goldman and Blobel, 1978). Antigen-antibody complexes were eluted from the protein A-Sepharose using either sample buffer or lysis buffer.

Electrophoresis. SDS-PAGE was carried out as previously described (Lee et al., 1981), using 7.5 to $15 \%$ gradient polyacrylamide slab gels and the discontinuous buffer system of Laemmli (1970). Molecular weights were estimated on the basis of the following markers: fibronectin, $M_{\mathrm{r}}=230,000$ (generous gift of Dr. D. Rifkin, New York University Medical Center); myosin, $M_{\mathrm{r}}=200,000$; 
$\beta$-galactosidase, $M_{\mathrm{r}}=116,000$; phosphorylase $\mathrm{B}, M_{\mathrm{r}}=$ 96,000 ; bovine serum alubmin, $M_{\mathrm{r}}=66,000$; and ovalbumin, $M_{\mathrm{r}}=45,000$ (all from Bio-Rad Laboratories). Fluorography was carried out using Enhance (New England Nuclear); Kodak S-R-5 x-ray film was presensitized as described by Laskey and Mills (1975). Autoradiograms were scanned using a Joyce Loebl microdensitometer. Alkali treatment of SDS-polyacrylamide gels with $1 \mathrm{M}$ $\mathrm{KOH}$ was carried out as described by Cooper and Hunter (1981).

Two-dimensional gel electrophoresis was carried out essentially by the procedure of O'Farrell (1975), modified as follows: Triton X-100 was used instead of NP40 in lysis buffer and isoelectric focusing gels, and either $\mathrm{pH} 6$ to 8 or $\mathrm{pH} 5$ to 7 Ampholines were combined with $\mathrm{pH}$ 3.5 to 10 Ampholines (LKB Instruments, Inc.). PC12 cells labeled with $\left[{ }^{3} \mathrm{H}\right]$ fucose were extracted in Buffer A without SDS, and the resulting immunoprecipitates were dissociated from protein A-Sepharose in lysis buffer containing $9.5 \mathrm{M}$ urea, $3 \%$ Triton $\mathrm{X}-100,1.5 \% \mathrm{pH} 6$ to 8 or 5 to 7 Ampholines, and $0.5 \% \mathrm{pH} 3.5$ to 10 Ampholines. Immunoprecipitates, from $\left[{ }^{32} \mathrm{P}\right]$ phosphate- or $\left[{ }^{35} \mathrm{~S}\right] \mathrm{me}$ thionine-labeled PC12 cells that had been extracted initially in $1 \%$ SDS, were removed from protein A-Sepharose in the above lysis buffer containing $9 \%$ Triton X-100 and were focused on isoelectric gels containing 6 to $9 \%$ Triton X-100.

\section{Results}

Phosphorylation of NILE GP. Because PC12 cells possess a number of phosphoproteins, some of which are NGF responsive (Halegoua and Patrick, 1980; Yu et al., 1980; End et al., 1982; Greene et al., 1983), experiments were performed to determine whether NILE GP was phosphorylated in the presence and absence of NGF. PC12 cultures were treated with NGF for various periods of time and then labeled for $2 \mathrm{hr}$ with $\left[{ }^{32} \mathrm{P}\right]$ orthophosphate. The labeled cells were extracted in detergent, and aliquots containing equal counts of trichloroacetic acidprecipitable radioactivity were immunoprecipitated with anti-NILE GP antiserum and analyzed by SDS-PAGE and autoradiography. A phosphorylated band comigrating with NILE GP was specifically immunoprecipitated from both NGF-treated and untreated PC12 cells (Fig. 1). This macromolecule appeared to be NILE GP on the basis of its comigration with $\left[{ }^{35} \mathrm{~S}\right]$ methionine- and $\left[{ }^{3} \mathrm{H}\right]$ fucose-labeled NILE GP on SDS gels, immunologic cross-reactivity, sensitivity to trypsin, two-dimensional gel electrophoretic pattern, and induction in NGFtreated cultures (see below). The incorporation of $\left[{ }^{32} \mathrm{P}\right]$ phosphate into this band was quantified by scintillation counting of labeled bands and densitometer scanning of the autoradiogram. Little increase was observed in cultures treated for 12 to $24 \mathrm{hr}$ with NGF (Fig. 1, lanes 2 and 3$)$. In contrast, a 3-fold increase in $\left[{ }^{32} \mathrm{P}\right]$ phosphate incorporation was detected in cultures treated with NGF for 7 days and a 4 - to 5 -fold increase for cultures exposed to NGF for 14 to 17 days (Fig. 1). Anti-NILE GP also immunoprecipitated a band of apparent $M_{\mathrm{r}}=225,000$ from ${ }^{32} \mathrm{P}$-labeled primary cultures of rat sympathetic neurons (Fig. $2 A$, lanes 1 and 2 ).

Two-dimensional gel analysis of immunoprecipitated

\section{7}

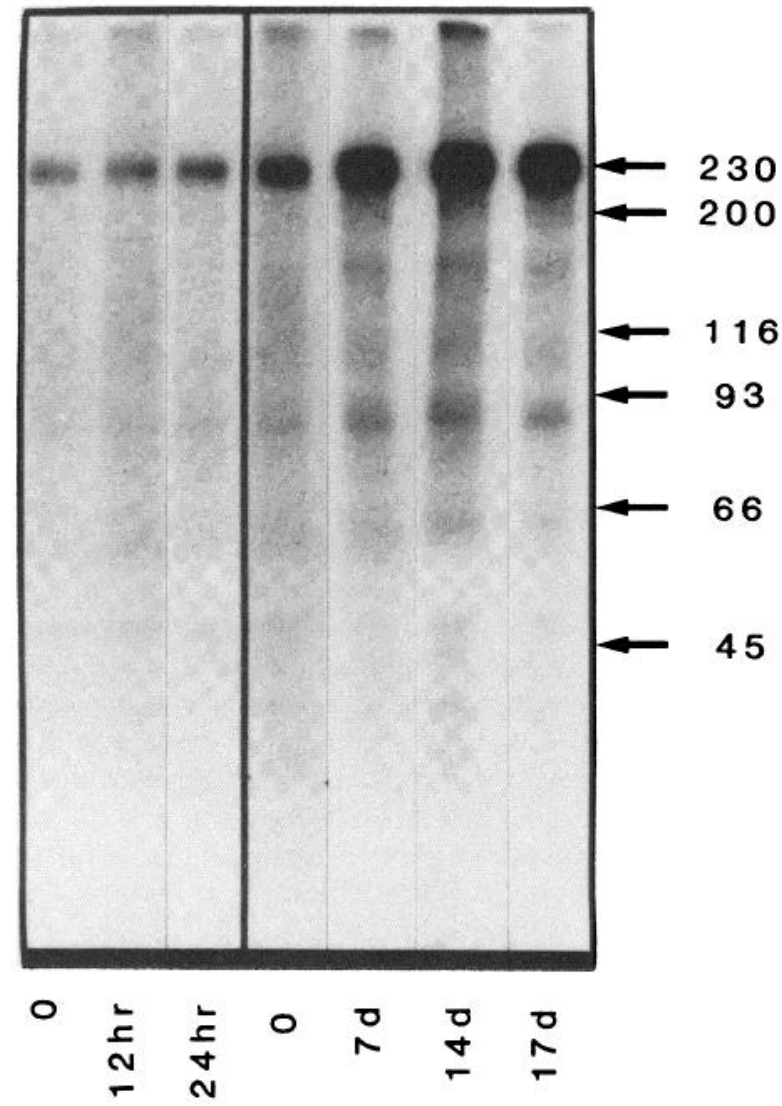

\section{NGF treatment}

Figure 1. Immunoprecipitation of phosphorylated NILE GP from extracts of PC12 cells. PC12 cells, untreated or treated with NGF, were labeled with $\left[{ }^{32} \mathrm{P}\right]$ phosphate, extracted, and subjected to immunoprecipitation with anti-NILE GP. The entire immunoprecipitates were solubilized and analyzed by SDS-PAGE and autoradiography (see "Experimental Procedures"). For lanes 1 to 3 , the aliquots each contained $10^{5}$ trichloroacetic acid-precipitable $\mathrm{cpm}$ prior to immunoprecipitation. These were derived from untreated PC12 cells (lane 1) and PC12 cells treated with NGF for 12 or $24 \mathrm{hr}$ (lanes 2 and 3 , respectively). For lanes 4 to 6 , aliquots containing $2.5 \times 10^{5}$ trichloroacetic acid-precipitable cpm of the following samples were immunoprecipitated: untreated PC12 cells (lane 4) and PC12 cells treated with NGF for 7,14 , or 17 days (lanes 5,6 , and 7 , respectively). Densitometer scanning of the autoradiogram revealed the following relative peak intensities of lanes 1 to 3 and 4 to 7 , respectively, with the density of the PC12 (-NGF) NILE GP peaks (lanes 1 and 4) normalized to 1: 1 , $1.1,1.3 ; 1,2.8,4.1,4.7$. No detectable labeled bands were immunoprecipitated by preimmune serum. Mobilities of molecular weight standards $\left(M_{\mathrm{r}} \times 10^{-3}\right)$ are indicated by arrows.

NILE GP. NGF-treated and untreated PC12 cultures were labeled with either $\left[{ }^{3} \mathrm{H}\right]$ fucose, $\left[{ }^{35} \mathrm{~S}\right]$ methionine, or $\left[{ }^{32} \mathrm{P}\right]$ orthophosphate and extracted in detergent, and aliquots containing equal numbers of counts from NGFtreated and untreated cells were immunoprecipitated with anti-NILE GP as described under "Experimental Procedures." Immunoprecipitates were solubilized in lysis buffer (O'Farrell, 1975) and were analyzed by isoe- 


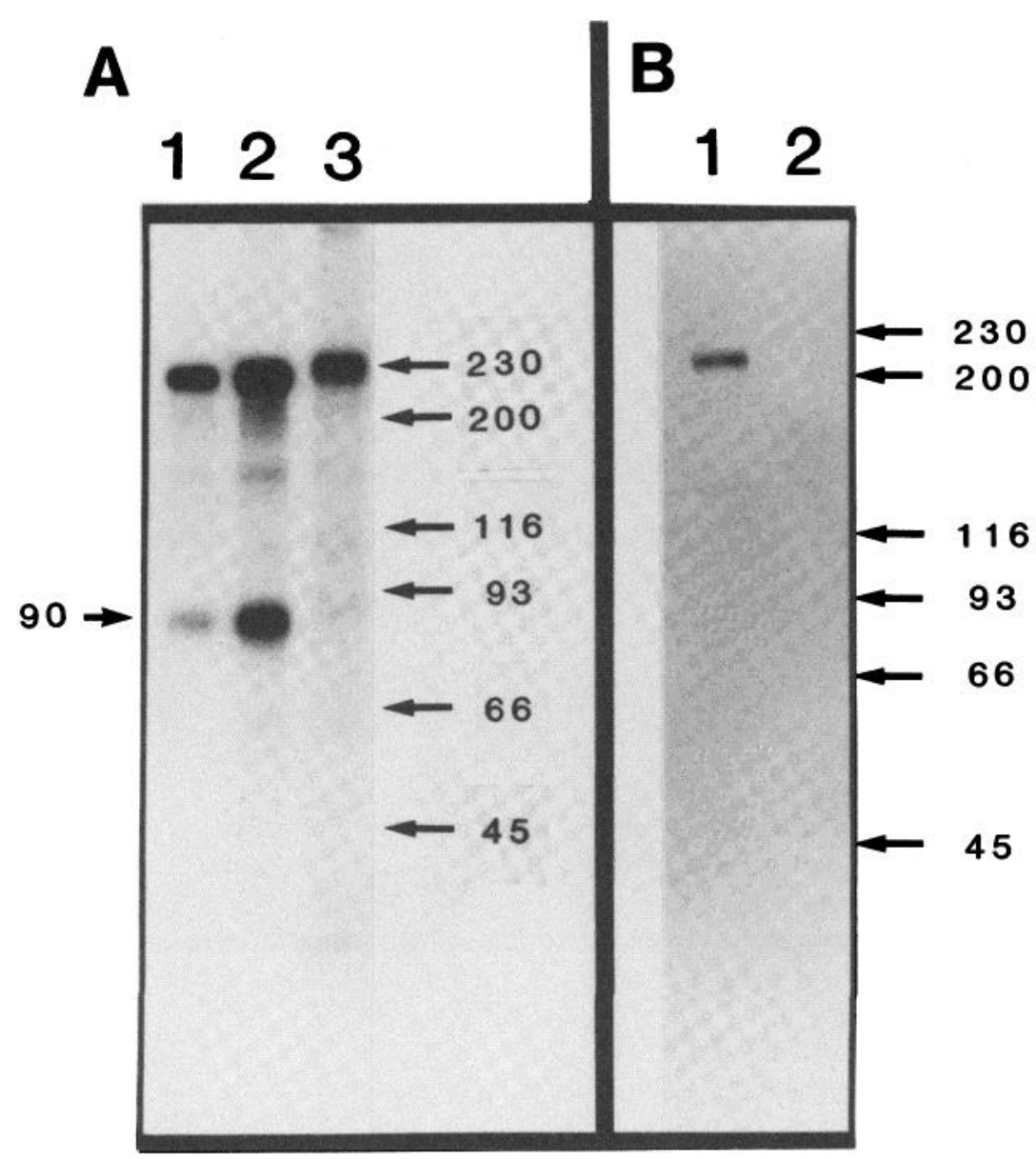

Figure 2. $A$, Immunoprecipitation of ${ }^{32} \mathrm{P}$-labeled NILE GP-cross-reactive material from sympathetic neurons. Cultured rat sympathetic neurons were labeled with $\left[{ }^{32} \mathrm{P}\right]$ phosphate, extracted, and analyzed by immunoprecipitation, SDS-PAGE, and autoradiography as described in the text. Aliquots of extract containing $100,000 \mathrm{cpm}$ (lane 1) and 250,000 cpm (lane 2) were immunoprecipitated with anti-NILE GP. An aliquot containing 100,000 cpm of ${ }^{32} \mathrm{P}$-labeled PC12 cells was similarly processed for comparison (lane 3). No labeled bands were immunoprecipitated by preimmune serum. Mobilities of molecular weight markers (given as $M_{\mathrm{r}} \times 10^{-3}$ ) are indicated by arrows on the right. $B$, Immunoprecipitation of NILE GP-cross-reactive material from rat brain labeled in situ with $\left[{ }^{3} \mathrm{H}\right]$ glucosamine. Rats were injected intracerebally with $\left[{ }^{3} \mathrm{H}\right]$ glucosamine and sacrificed after $18 \mathrm{hr}$, and their brains were removed and extracted in Buffer A, all as described under "Experimental Procedures." Aliquots of labeled extract, containing 100,000 cpm, were immunoprecipitated with either anti-NILE GP (lane 1) or preimmune serum (lane 2) and analyzed by SDS-PAGE and fluorography. Mobilities of molecular weight markers (given as $M_{\mathrm{r}} \times 10^{-3}$ ) are indicated by arrows.

lectric focusing in the first dimension and SDS-PAGE in the second. The gels from $\left[{ }^{3} \mathrm{H}\right]$ fucose-labeled $\mathrm{PC} 12$ cells revealed two tightly clustered spots, each of which increased in NGF-treated cultures (Fig. 3, $a$ and $c$ ). The pI's of these species were determined to be between 6.4 and 6.5 , using either $\mathrm{pH} 5$ to 7 or $\mathrm{pH} 6$ to 8 Ampholines. Similar electrophoretic profiles and isoelectric points were obtained with anti-NILE GP immunoprecipitates of PC12 cells labeled with either $\left[{ }^{32} \mathrm{P}\right]$ phosphate (Fig. 3 b) or $\left[{ }^{35} \mathrm{~S}\right]$ methionine.

The residues at which phosphate is attached to NILE GP were examined by taking advantage of the differential susceptibilities of serine, threonine, and tyrosine phosphodiester bonds to alkali hydrolysis in $1 \mathrm{M} \mathrm{KOH}$
(Cooper and Hunter, 1981). NILE GP from PC12 cells was metabolically labeled with $\left[{ }^{32} \mathrm{P}\right]$ phosphate and then immunoprecipitated and analyzed by two-dimensional electrophoresis. The two-dimensional gel was autoradiographed for 5 days (Fig. $3 b$ ) and then treated with $1 \mathrm{M}$ $\mathrm{KOH}$ for 2 to $3 \mathrm{hr}$ at $55^{\circ} \mathrm{C}$. The gel was then redried and autoradiographed for 9 days (Fig. $3 d$ ). Only a small fraction of the ${ }^{32} \mathrm{P}$ labeling of each immunoprecipitable spot appeared to be alkali resistant (Fig. 3d). In control experiments, NILE GP, labeled with $\left[{ }^{35}\right.$ S $]$ methionine, and a number of other ${ }^{32} \mathrm{P}$-labeled components from crude detergent extracts of PC12 cells were not affected by alkali treatment.

Membrane orientation of NILE GP. Previous studies 


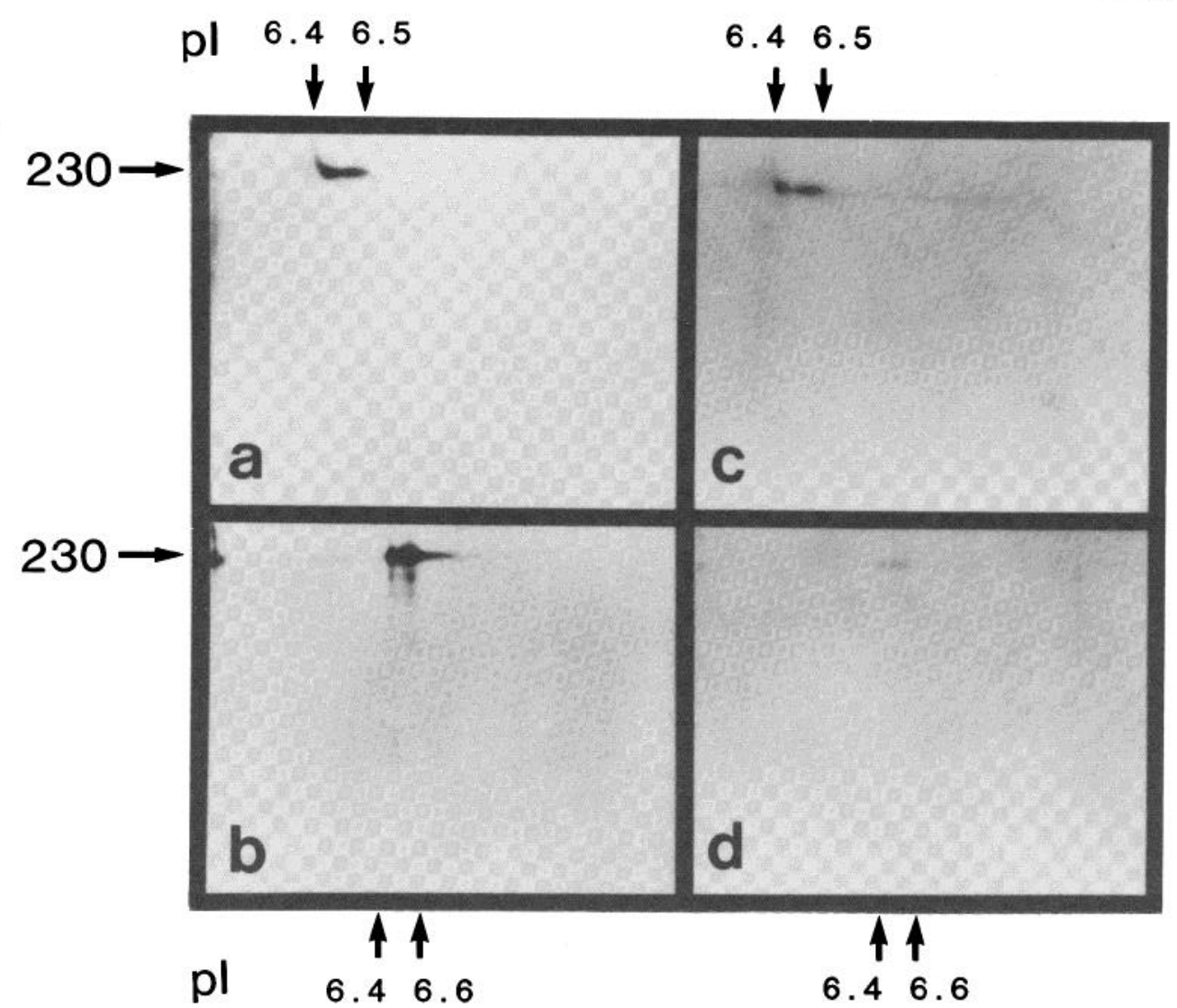

Figure 3. Two-dimensional gel analysis of immunoprecipitated NILE GP. PC12 cells were radiolabeled and extracted in detergent. Aliquots of the following samples were immunoprecipitated with anti-NILE GP and analyzed by two-dimensional electrophoresis and autoradiography or fluorography as described under "Experimental Procedures": $10^{5}$ trichloroacetic acid-precipitable cpm of $\left[{ }^{3} \mathrm{H}\right]$ fucose-labeled PC12 cells cultured with NGF for 2 weeks $(a)$ or without NGF $(c)$ and $10^{7}$ trichloroacetic acid-precipitable cpm of $\left[{ }^{32} \mathrm{P}\right]$ phosphate-labeled NGF-treated PC12 cells $(b)$. In $d$, the gel whose autogradiogram is shown in $b$ was treated with $1 \mathrm{~N} \mathrm{KOH}$, and then redried and autoradiographed. The position of the marker fibronectin $\left(M_{\mathrm{r}}=230,000\right)$ in the second dimension is indicated by the arrows on the left.

(Salton et al., 1983) showed that mild trypsinization of intact PC12 cells (50 to $100 \mu \mathrm{g} / \mathrm{ml}$ for $15 \mathrm{~min}$ ) at $37^{\circ} \mathrm{C}$ converted the NILE GP (apparent $M_{\mathrm{r}}=230,000$ ), at least in part, into a fucosylated membrane-associated immunoreactive fragment of apparent $M_{\mathrm{r}}=90,000$. In the current studies, when PC12 cells were exposed to longer incubations (50 to $100 \mu \mathrm{g} / \mathrm{ml}$ for $1 \mathrm{hr}$ or more) or treatment with higher concentrations of trypsin (250 to $1000 \mu \mathrm{g} / \mathrm{ml}$ for $30 \mathrm{~min}$ ), a fucose-labeled component could no longer be immunoprecipitated from membrane fractions. Labeling of $\mathrm{PC} 12$ cells with $\left[{ }^{32} \mathrm{P}\right]$ phosphate, followed by trypsinization $(100 \mu \mathrm{g} / \mathrm{ml})$ for $15 \mathrm{~min}$, resulted in the production of a prominent, labeled, membrane-bound immunoprecipitable component of apparent $M_{\mathrm{r}}=90,000$, and less prominent, labeled, membranebound immunoprecipitable fragments of apparent $M_{\mathrm{r}}=$ $40,000,32,000$, and 28,000 . Treatment of PC12 cells ( \pm NGF) with trypsin $(100 \mu \mathrm{g} / \mathrm{ml})$ in the presence of $\left[{ }^{32} \mathrm{P}\right]$ phosphate for 2 to $3 \mathrm{hr}$ followed by immunoprecipitation in the presence of phosphatase inhibitors resulted in the detection of an intensely labeled fragment of apparent $M_{\mathrm{r}}=28,000$ (Fig. 4, lanes 2 and 4) that was membrane associated (Fig. 4, lane 4). As shown in Figure 2, incu- bation of cultured sympathetic neurons with $\left[{ }^{32} \mathrm{P}\right]$ phosphate followed by extraction in detergent and immunoprecipitation with anti-NILE GP demonstrated not only labeling of the $M_{\mathrm{r}}=225,000$ NILE-cross-reactive GP, but also detectable levels of a component of $M_{\mathrm{r}}=90,000$ and several additional minor bands of higher apparent molecular weight. The presence of the latter suggests a degree of in situ processing or proteolysis during extraction in these cultures.

Several criteria (Kreibich et al., 1978) were applied to determine whether NILE GP is an integral membrane protein. PC12 cells that had been labeled with $\left[{ }^{3} \mathrm{H}\right]$ fucose (Fig. 5, lanes 1 to 6 ) or $\left[{ }^{3} \mathrm{H}\right]$ glucosamine (Fig. 5 , lanes 7 and 8) were treated for $30 \mathrm{~min}$ at $4^{\circ} \mathrm{C}$ with either PBS, $0.1 \mathrm{~N} \mathrm{NaOH}, 0.025 \mathrm{~N} \mathrm{NaOH}, 5 \mathrm{~mm}$ EDTA $(\mathrm{pH} 7.4$ ), or $0.5 \mathrm{~N}$ acetic acid and then centrifuged under the same conditions at $143,000 \times g$ for $1 \mathrm{hr}$. The supernatants and pellets were each combined with Buffer A and analyzed by immunoprecipitation and SDS-PAGE. Figure 5 reveals that, in each case, the major immunoprecipitable component was intact NILE GP which remained in the membrane pellet. Only comparatively small amounts of NILE GP (apparent $M_{\mathrm{r}}=230,000$ ) were immunoprecip- 


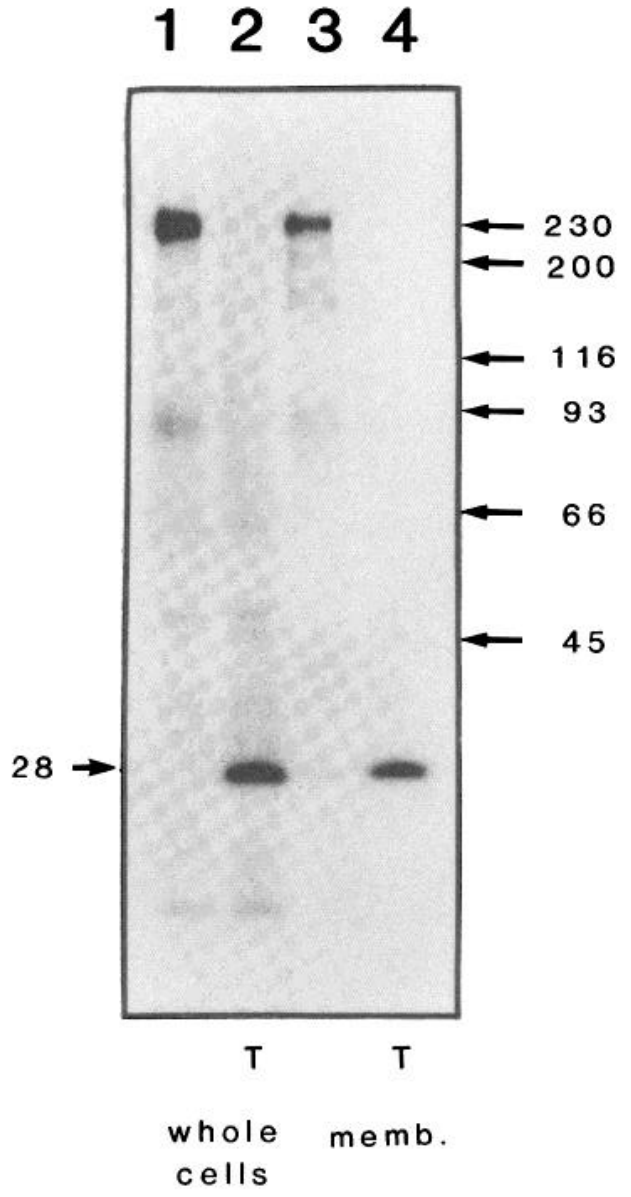

Figure 4. Immunoprecipitation of extracts from trypsinized PC12 cells labeled with $\left[{ }^{32} \mathrm{P}\right]$ phosphate. NGF-treated PC12 cells were labeled for $3 \mathrm{hr}$ with $\left[{ }^{32} \mathrm{P}\right]$ phosphate in the presence or absence of trypsin. A crude membrane fraction was prepared from some of these cultures, as described under "Experimental Procedures." Both intact PC12 cells and PC12 cell membrane preparations were then extracted in detergent, and immunoprecipitation, SDS-PAGE, and autoradiography were carried out according to "Experimental Procedures." Lanes 1 and 2 show bands immunoprecipitated by anti-NILE GP from aliquots containing $125,000 \mathrm{cpm}$ of extracts of untrypsinized and trypsinized intact PC12 cells, respectively. Lanes 3 and 4 show material immunoprecipitated by anti-NILE GP from aliquots (containing 75,000 cpm) of the crude membrane preparation of untrypsinized and trypsinized PC12 cells, respectively. Positions of molecular weight markers $\left(M_{\mathrm{r}} \times 10^{-3}\right)$ are indicated by the arrows on the right.

itated from the supernatants of PC12 cells treated with $0.1 \mathrm{~N} \mathrm{NaOH}, 0.025 \mathrm{~N} \mathrm{NaOH}, 0.5 \mathrm{~N}$ acetic acid, or $5 \mathrm{~mm}$ EDTA (Fig. 5, lanes 3, 5, and 7). No labeled bands were immunoprecipitated by preimmune sera. These solubility properties suggest that NILE GP is an integral membrane component.

Anti-NILE GP also immunoprecipitated a significant amount of a glycoprotein of apparent $M_{\mathrm{r}}=210,000$ from the supernatants of PC12 cells treated with PBS or 5 mM EDTA (Fig. 5, lanes 1 and 3). This component may be identical to the soluble apparent $M_{\mathrm{r}}=210,000$ glycoprotein which can be immunoprecipitated from PC12conditioned culture medium with anti-NILE GP (C.
Richter-Landsberg, S. R. J. Salton, M. L. Shelanski, and L. A. Greene, manuscript in preparation) and with antiPC12 cell antisera (Richter-Landsberg et al., 1979; Stallcup et al., 1983). A much smaller amount of the 210,000 dalton glycoprotein was immunoprecipitated from the supernatants of PC12 cells treated with $\mathrm{NaOH}$ or acetic acid (Fig. 5, lanes 5 and 7). Minor immunoprecipitable membrane-bound bands of 170,000 and 90,000 daltons were also detected. These were most likely produced by proteolysis during the experiment since they are very similar in mobility to components produced by limited trypsinization.

Macromolecular properties of immunoreactive NILE GP. Anti-NILE GP has been shown to selectively immunoprecipitate a glycoprotein of apparent $M_{\mathrm{r}}=225,000$ to 230,000 from PC12 cells and cultured sympathetic and sensory neurons, and a glycoprotein of apparent $M_{\mathrm{r}}=$ 200,000 to 210,000 from cultured cerebellum, cerebral cortex, and spinal cord (Lee et al., 1981; Salton et al., 1983; Stallcup et al., 1983). In order to determine the apparent molecular weight of immunoreactive NILE GP in the mature intact CNS, brains of 30-day-old rats were labeled by intracerebral injection of $\left[{ }^{3} \mathrm{H}\right]$ glucosamine. Anti-NILE GP was found to selectively immunoprecipitate a glycoprotein of apparent $M_{\mathrm{r}}=200,000$ to 210,000 from these brains (Fig. 2B, lane 1). This band comigrated on SDS gels with the NILE-cross-reactivity glycoprotein that was immunoprecipitated from primary cultures of rat cerebral cortex. Such findings not only suggest that the apparent molecular weight of NILE GP-cross-reactive material observed in culture reflects that in the nervous system in situ, but also confirm that PNS and CNS forms of this material have consistently different mobilities by SDS-PAGE analysis.

Studies were undertaken to determine whether the differences in apparent molecular weight of CNS and PNS NILE GP are due to variation in the glycosylation of a common apoprotein and/or to the existence of two or more classes of cross-reactive but variably sized apoproteins. Tunicamycin was used to inhibit $\mathrm{N}$-linked glycosylation (Waechter and Lennarz, 1976; Hubbard and Ivatt, 1981). Cultured cerebral cortex and cerebellum, and NGF-treated and untreated PC12 cells were labeled with either $\left[{ }^{35} \mathrm{~S}\right]$ methionine or $\left[{ }^{3} \mathrm{H}\right]$ glucosamine in the presence or absence of tunicamycin ( 2 to $5 \mu \mathrm{g} / \mathrm{ml})$, as describedunder "Experimental Procedures." At these concentrations, tunicamycin inhibited the incorporation of $\left[{ }^{3} \mathrm{H}\right]$ glucosamine in these cultures by 90 to $95 \%$, and inhibited incorporation of $\left[{ }^{35} \mathrm{~S}\right]$ methionine by $0 \%$ in NGF-untreated PC12 cells and 40 to $60 \%$ in NGF-treated PC12 cells and cultured cerebral cortex and cerebellum. In the absence of tunicamycin, anti-NILE GP immunoprecipitated a band of approximate $M_{\mathrm{r}}=230,000$ from PC12 cells labeled with $\left[{ }^{35} \mathrm{~S}\right]$ methionine (Fig. 6, lane 5) or with $\left[{ }^{3} \mathrm{H}\right]$ glucosamine, and a band of $M_{\mathrm{r}}=200,000$ to 210,000 from cerebral cortex cultures labeled with $\left[{ }^{35} \mathrm{~S}\right]$ methionine (Fig. 6, lane 8) or $\left[{ }^{3} \mathrm{H}\right]$ glucosamine. In contrast, with detergent extracts of tunicamycin-treated PC12 cells (Fig. 6, lane 3), cultured cerebellum, and cultured cerebral cortex (Fig. 6 , lane 2 ) labeled with $\left[{ }^{35} \mathrm{~S}\right]$ methionine, anti-NILE GP selectively immunoprecipi- 


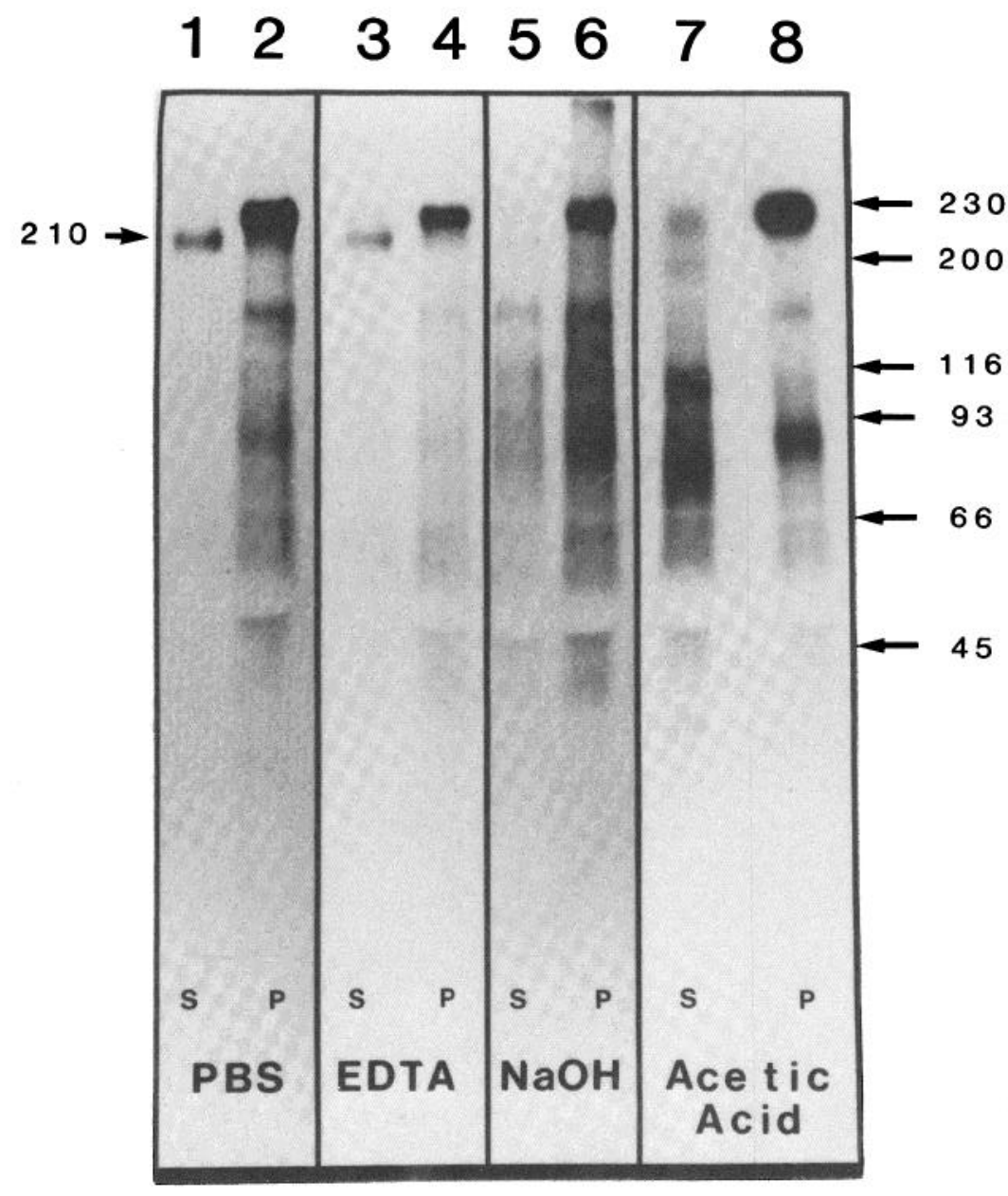

Figure 5. Solubility properties of NILE GP. NGF-treated PC12 cultures were labeled with $\left[{ }^{3} \mathrm{H}\right]$ fucose or $\left[{ }^{3} \mathrm{H}\right]$ glucosamine for $72 \mathrm{hr}$ and then treated with either PBS (lanes 1 and 2), $5 \mathrm{~mm}$ EDTA (lanes 3 and 4), $0.1 \mathrm{~N} \mathrm{NaOH}$ (not shown), $0.025 \mathrm{~N} \mathrm{NaOH}$ (lanes 5 and 6), or $0.5 \mathrm{~N}$ acetic acid (lanes 7 and 8 ). Pellets and supernatants were obtained by centrifugation. Aliquots containing $100,000 \mathrm{cpm}$ of each pellet (lanes 2, 4, 6, and 8) and 50,000 (lanes 1 and 3) or 100,000 (lanes 5 and 7) cpm of each supernatant were immunoprecipitated with anti-NILE GP and analyzed by SDS-PAGE and fluorography, as described under "Experimental Procedures." No detectable labeled bands were immunoprecipitated by preimmune serum. Mobilities of molecular weight standards (given as $M_{\mathrm{r}} \times 10^{-3}$ ) are indicated by the arrows.

tated a band of apparent $M_{\mathrm{r}}=160,000$. In each of the three cell types, the bands migrated with extremely similar and, in some experiments, identical mobilities. No detectable bands were immunoprecipitated from tunicamycin-treated cultures labeled with $\left[{ }^{3} \mathrm{H}\right]$ glucosamine.

\section{Discussion}

The PC12 cell line has been used as a model system for studying neuronal development and maturation and investigating, in particular, the mechanism by which NGF triggers the differentiation of target cells into neurons. NILE GP is one of a restricted number of macromolecules whose specific levels increase during neuronal differentiation of PC12 cells. Calculations suggest that each NGF-treated PC12 cell contains approximately $10^{4}$ to $10^{5}$ molecules of NILE GP (Salton, 1983), as compared with $5 \times 10^{4}$ saxitoxin binding sites (Rudy et al., 1982), and the same order of magnitude of NGF receptors (Yankner and Shooter, 1979). Immunologically crossreactive NILE GP, although undetectable in a variety of non-neural tissues, has been identified on the surfaces of all central and peripheral neurons examined, and in all four of the mammalian species tested thus far (Salton et al., 1983). To further investigate the role that this macromolecule may play in the development and/or maintenance of the nervous system, several of the biochemical properties of NILE-cross-reactive glycoprotein have been investigated.

Phosphorylation of NILE GP. Phosphorylation of selected macromolecular substrates appears to be an im- 


\section{8}

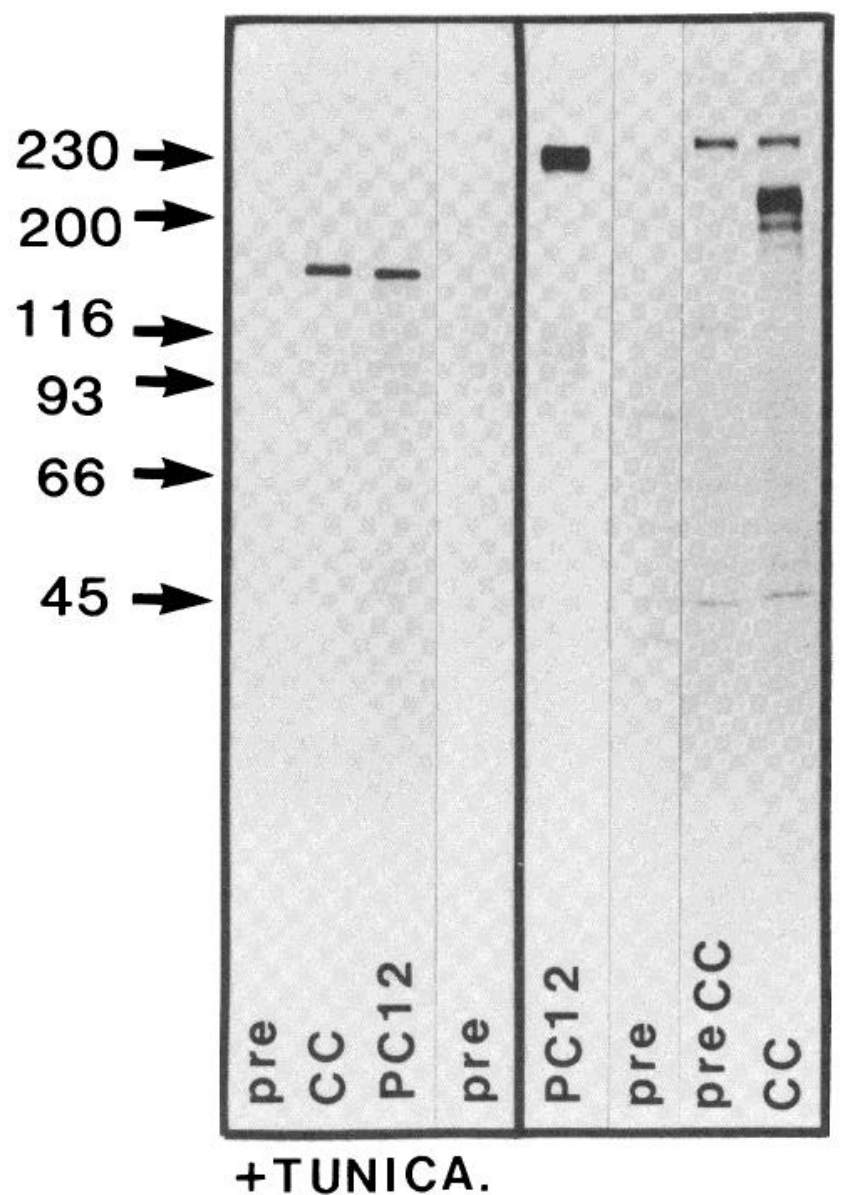

Figure 6. Immunoprecipitation analysis of tunicamycintreated cells. NGF-treated PC12 cells and cultured cerebral cortex were labeled as described under "Experimental Procedures" with $\left[{ }^{35} \mathrm{~S}\right]$ methionine in the presence or absence of tunicamycin (2 to $5 \mu \mathrm{g} / \mathrm{ml})$, and immunoprecipitation with antiNILE GP, SDS-PAGE, and fluorography was carried out. Aliquots from the following samples were immunoprecipitated with anti-NILE GP: tunicamycin-treated cortical cultures $(C C$; lane 2), tunicamycin-treated PC12 cells (lane 3), PC12 cells (lane 5), and cortical cultures (lane 8). Lanes 1, 4,6, and 7 were generated by immunoprecipitation with preimmune serum (pre) of the following samples: tunicamycin-treated cortical cultures (lane 1), tunicamycin-treated PC12 cells (lane 4), PC12 cells (lane 6), and cortical cultures (lane 7). Experiments with NGF-untreated PC12 cells yielded results similar to those shown here for NGF-treated PC12 cells. Note that the $M_{\mathrm{r}}=$ 240,000 band in lane 8 is also present in the sample precipitated with preimmune serum (lane 7). The minor band of apparent $M_{\mathrm{r}}=180,000$ in lane 8 may be due to proteolysis of CNS NILE GP-cross-reactive material during the experiment or to processing in situ as discussed in the text. Positions of molecular weight standards (given as $M_{r} \times 10^{-3}$ ) are indicated by the arrows.

portant cellular regulatory mechanism (Cohen, 1982), and there is now abundant evidence for the phosphorylation of specific proteins in the nervous system (cf. Sieghart et al., 1979; Bloom et al., 1979). The present study examined whether NILE GP is a phosphoprotein and whether the phosphorylation of this component is regulated by NGF. Anti-NILE GP was found to immunoprecipitate from PC12 cells a phosphorylated macromolecule with the same mobility, by SDS-PAGE, trypsin sensitivity, and two-dimensional gel pattern, as NILE GP. In NGF-treated PC12 cells, both the phosphorylation and the specific amount of NILE GP fail to increase significantly over the first 12 to $24 \mathrm{hr}$. Thus, NILE GP does not appear to be among the selected PC12 proteins whose phosphorylation is rapidly and extensively altered by NGF (Halegoua and Patrick, 1980; Yu et al., 1980; Greene et al., 1983). On the other hand, the relative incorporation of phosphate into NILE GP increased over a period of several days of NGF treatment, reaching levels after 2 weeks that were approximately 3 - to 5 -fold greater than those of untreated PC12 cells. This change in relative phosphate incorporation appears to parallel the previously demonstrated (Salton et al., 1983) increase in the relative abundance of NILE GP in NGF-treated PC12 cells, with respect to both the rate and the level of induction achieved. Therefore, the apparent relative increase in the incorporation of ${ }^{32} \mathrm{P}$ into NILE GP most likely reflects the increased level of NILE GP in NGFtreated PC12 cells rather than a selective alteration in phosphorylation.

Although NILE GP is phosphorylated, this component does not appear to be a phosphotransferase (Salton, 1983). NILE GP did not detectably catalyze its own phosphorylation or that of either immunoglobulin heavy or light chains when anti-NILE GP immunoprecipitates were incubated with $\left[\gamma_{-}{ }^{32} \mathrm{P}\right] \mathrm{ATP}$, according to published methods (Collett and Erikson, 1978).

The finding that phosphorylation of NILE GP is almost completely alkali labile indicates that most of the phosphate groups are attached at serine residues (Cooper and Hunter, 1981). The resistance of a small portion of phosphate labeling to alkali hydrolysis leaves open the possibility that NILE GP possesses a limited number of phosphothreonine or phosphotyrosine residues, although more rigourous studies will be necessary to test this.

Glycosylation of NILE and NILE-cross-reactive GP. The present studies demonstrated that the distinction between the central (apparent $M_{\mathrm{r}}=200,000$ to 210,000 ) and peripheral (apparent $M_{\mathrm{r}}=225,000$ to 230,000 ) forms of immunoreactive NILE GP appears to be due to variation in the glycosylation of a similarly sized apoprotein. Anti-NILE GP immunoprecipitates nonglycosylated proteins of apparent $M_{\mathrm{r}}=160,000$ from tunicamycintreated cultures of PC12 cells $( \pm \mathrm{NGF})$ and dissociated cerebellum and cerebral cortex. Of relevance to this, differences in the structures and relative abundances of brain and PC12 cell total glycoprotein-associated complex oligosaccharides have been demonstrated in recent studies using sequential lectin affinity chromatography (Margolis et al., 1983a). Furthermore, carbohydrate analysis suggests that the larger molecular size of tri- and tetra-antennary oligosaccharide moieties of PC12 NILE GP as compared with the corresponding oligosaccharides of brain NILE-cross-reactive GP accounts for the molecular weight difference between the two glycoproteins (Margolis et al., 1983b). Taken together, these experiments imply that very similar, or possibly identical, NILE apoproteins can be glycosylated in different patterns depending on the tissue or cell of origin. In agree- 
ment with the complete inhibition of NILE GP glycosylation by tunicamycin reported here, NILE GP appears to possess only N-linked carbohydrate chains (Margolis et al., 1983b).

Biochemical properties of PC12 NILE GP. The PC12 cell components recognized by anti-NILE GP were characterized by two-dimensional gel electrophoresis. Analyses of immunoprecipitates of either $\left[{ }^{3} \mathrm{H}\right]$ fucose-, $\left[{ }^{35} \mathrm{~S}\right]$ methionine-, or $\left[{ }^{32} \mathrm{P}\right]$ phosphate-labeled PC12 cells have revealed two tightly clustered spots of apparent $M_{\mathrm{r}}$ $=230,000$, each of which is induced in NGF-treated PC12 cells. Variable glycosylation and/or phosphorylation of a single apoprotein may be responsible for this heterogeneity. The apparent isoelectric point and distribution of spots obtained in the current two-dimensional gel studies of anti-NILE GP immunoprecipitates closely resemble those found previously for NILE GP derived from lysates of glucosamine-labeled PC12 cells (McGuire et al., 1978). These patterns are also very similar to several of the membrane glycoproteins on cultured rat sympathetic neurons described by Braun et al. (1981).

Current studies suggest that NILE GP $\left(M_{r}=230,000\right)$ is an integral membrane glycoprotein since it remains almost exclusively insoluble following treatment with either $\mathrm{NaOH}$, acetic acid, PBS, or EDTA, and can be solubilized with ionic and non-ionic detergents (Salton et al., 1983). Anti-NILE GP also recognizes a soluble 210,000-dalton glycoprotein that is released from PC12 cells in the absence of detergent and that is probably identical to the soluble 210,000-dalton NILE-cross-reactive glycoprotein released by PC12 cells and rat sympathetic neurons into culture medium (Richter-Landsberg et al., 1979; C. Richter-Landsberg, S. R. J. Salton, M. L. Shelanski, and L. A. Greene, manuscript in preparation). It is not known whether NILE GP is released as a 230,000-dalton component and rapidly converted to a 210,000-dalton component, or whether the cleavage occurs prior to release. A soluble 230,000-dalton component has not been detected in $\mathrm{PC} 12$-conditioned medium or PBS, but is apparently released in small amounts after treatment with $\mathrm{NaOH}$, acetic acid, or EDTA. This implies that a fraction of NILE GP may be loosely associated with the cell membrane or releasable within the cell.

The present experiments demonstrated production of a membrane-associated, immunoreactive 28,000-dalton nonfucosylated fragment of NILE GP following exhaustive trypsin treatment of intact cells. These findings suggest that this portion of the macromolecule is very

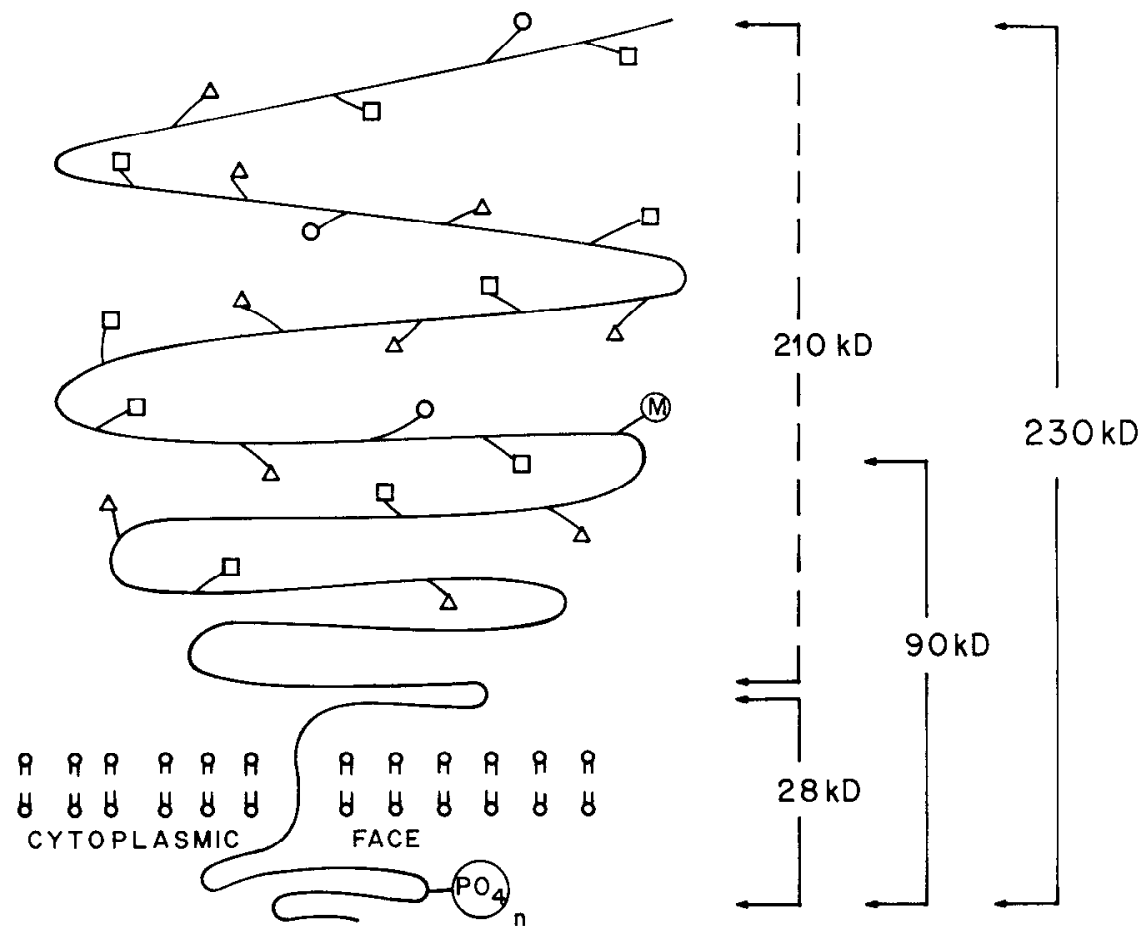

Figure 7. Schematic model of NILE GP and its association with the PC12 cell surface. PC12 cell NILE GP is shown as a phosphorylated integral membrane glycoprotein that penetrates the lipid bilayer. The relative distribution of $\mathrm{N}$ linked complex oligosaccharides (Margolis et al., 1983b) on the 160,000-dalton apoprotein is depicted using the following symbols: $\square$, tetra-antennary; $\Delta$, triantennary; $O$, biantennary; and $(M)$, high-mannose oligosaccharides. The intact carbohydrate-containing molecule has an $M_{\mathrm{r}}=230,000$ by SDS-PAGE. Mild trypsinization generates an $M_{\mathrm{r}}=90,000$ immunoreactive membrane-bound fragment which contains both phosphate and carbohydrate moieties. Further trypsinization produces an immunoreactive $M_{\mathrm{r}}=28,000$ membrane-bound fragment which contains at least a single phosphoamino acid but no detectable carbohydrate. A soluble immunoreactive $M_{\mathrm{r}}=210,000$ form of NILE GP is also released into the medium. Release may involve a relatively selective proteolytic clip; the site of this proteolysis is uncertain as is the precise relationship between the $M_{\mathrm{r}}$ $=210,000$ form and the $M_{\mathrm{r}}=28,000$ fragment. 
tightly associated with and unexposed on the surface of the plasma membrane. It is not known whether a similar fragment remains membrane associated following release of the soluble NILE GP-cross-reactive component of apparent $M_{\mathrm{r}}=210,000$. A possible model of membraneassociated PC12 cell NILE GP consistent with the above structural data is depicted in Figure 7.

Anti-NILE GP was shown here to recognize the nonglycosylated apoprotein from tunicamycin-treated cells as well as the non-glycosylated phosphorylated fragment generated by trypsinization of PC12 cells. These observations suggest that polyclonal antisera against NILE GP recognize non-carbohydrate determinants, at least in part, and may therefore prove useful in investigation of the expression and biosynthetic regulation of this widely distributed neuronal glycoprotein.

\section{References}

Akeson, R., and W. C. Hsu (1978) Identification of a high molecular weight nervous system specific cell surface glycoprotein on murine neuroblastoma cells. Exp. Cell Res. 115: 367-377.

Barondes, S. H., and S. D. Rosen (1976) Cell surface carbohydrate-binding proteins: Role in cell recognition. In Neuronal Recognition, S. H. Barondes, ed., pp. 331-356, Plenum Press, New York.

Bloom, F. E., T. Ueda, E. Battenberg, and P. Greengard (1979) Immunocytochemical localization, in synapses, of protein I, an endogenous substrate for protein kinases in mammalian brain. Proc. Natl. Acad. Sci. U. S. A. 76: 5982-5986.

Braun, S. J., K. J. Sweadner, and P. H. Patterson (1981) Neuronal cell surfaces: Distinctive glycoproteins of cultured adrenergic and cholinergic sympathetic neurons. J. Neurosci. 1: 1397-1406.

Cohen, P. (1982) The role of protein phosphorylation in neural and hormonal control of cellular activity. Nature 296: 613620 .

Collett, M. S., and R. L. Erikson (1978) Protein kinase activity associated with the avian sarcoma virus src gene product. Proc. Natl. Acad. Sci. U. S. A. 75: 2021-2024.

Cooper, J. A., and T. Hunter (1981) Changes in protein phosphorylation in Rous sarcoma virus transformed chicken embryo cells. Mol. Cell. Biol. 1: 165-178.

Dulbecco, R., and M. Vogt (1954) Plaque formation and isolation of pure lines with poliomyelitis viruses. J. Exp. Med. 99: 167-182.

End, D., M. Hanson, S. Hashimoto, and G. Guroff (1982) Inhibition of the phosphorylation of a 100,000-dalton soluble protein in whole cells and cell-free extracts of $\mathrm{PC} 12$ pheochromocytoma cells following treatment with nerve growth factor. J. Biol. Chem. 257: 9223-9225.

Fuji, D. K., S. L. Massoglia, N. Savion, and D. Gospodarowicz (1982) Neurite outgrowth and protein synthesis by PC12 cells as a function of substratum and nerve growth factor. J. Neurosci. 2: 1157-1175.

Garrels, J. I., and D. Schubert (1979) Modulation of protein synthesis by nerve growth factor. J. Biol. Chem. 254: 79787985.

Goldman, B. M., and G. Blobel (1978) Biogenesis of peroxisomes: Intracellular site of synthesis of catalase and uricase. Proc. Natl. Acad. Sci. U. S. A. 75: 5066-5070.

Greene, L. A., and G. Rein (1977) Release, storage and uptake of catecholamines by a clonal cell line of nerve growth factor (NGF) responsive pheochromocytoma cells. Brain Res. 129: 247.263.

Greene, L. A., and G. Rein (1978) Short-term regulation of catecholamine synthesis in an NGF-responsive clonal line of rat pheochromocytoma cells. J. Neurochem. 30: 549-555.

Greene, L. A., and A. S. Tischler (1976) Establishment of a noradrenergic clonal line of rat adrenal pheochromocyloma cells which respond to nerve growth factor. Proc. Natl. Acad. Sci. U. S. A. 73: 2424-2428.

Greene, L. A., and A. S. Tischler (1982) PC12 pheochromocytoma cultures in neurobiological research. Adv. Cell. Neurobiol. 3: 373-414.

Greene, L. A., R. K. H. Liem, and M. L. Shelanski (1983) Regulation of a high molecular weight microtuble-associated protein in PC12 cells by nerve growth factor. J. Cell Biol. 96: $76-83$.

Halegoua, S., and J. Patrick (1980) Nerve growth factor mediates phosphorylation of specific proteins. Cell 22: 571-581.

Hatten, M. E. (1981) Cell assembly patterns of embryonic mouse cerebellar cells on carbohydrate-derivatized polylysine culture substrata. J. Cell Biol. 89: 54-61.

Hubbard, S. C., and R. J. Ivatt (1981) Synthesis and processing of asparagine-labeled oligosaccharides. Annu. Rev. Biochem. 50: $555-583$.

Kreibich, G., B. L. Ulrich, and D. D. Sabatini (1978) Proteins of rough microsomal membranes related to ribosome binding. I. Identification of Ribophorins I and II, membrane proteins characteristic of rough microsomes. J. Cell Biol. 77: 464-487.

Laemmli, U. K. (1970) Cleavage of structural proteins during the assembly of the head of bacteriophage 'I' 4 . Nature 227: 680-685.

Laskey, R. A., and A. D. Mills (1975) Quantitative film detection of ${ }^{3} \mathrm{H}$ and ${ }^{14} \mathrm{C}$ in polyacrylamide gels by fluorography. Eur. J. Biochem. 56: 335-341.

Lee, V., L. A. Greene, and M. L. Shelanski (1981) Identification of neural and adrenal medullary surface membrane glycoproteins recognized by antisera to cultured rat sympathetic neurons and PC12 pheochromocytoma cells. Neuroscience 6 : 2773-2786.

Linne, T., and L. Philipson (1980) Further characterization of the phosphate moiety of the adenovirus type 2 DNA-binding protein. Eur. J. Biochem. 103: 259-270.

Littauer, U. Z., M. Y. Giovanni, and M. C. Glick (1980) A glycoprotein from neurites of differentiated neuroblastoma cells. J. Biol. Chem. 255: 5448-5453.

Margolis, R. K., S. R. J. Salton, and R. U. Margolis (1983a) Complex carbohydrates of cultured PC12 pheochromocytoma cells. Effects of nerve growth factor and comparison with neonatal and mature rat brain. J. Biol. Chem. 258: 41104117.

Margolis, R. K., S. R. J. Salton, and R. U. Margolis (1983b) Structural features of the nerve growth factor inducible large external (NILE) glycoprotein of PC12 pheochromocytoma cells and brain. J. Neurochem., in press.

McClain, D. A., and G. E. Edelman (1982) A neural cell adhesion molecule from human brain. Proc. Natl. Acad. Sci. U. S. A. 79: $6380-6384$.

McGuire, J. C., L. A. Greene, and A. V. Furano (1978) NGF stimulates incorporation of fucose or glucosamine into an external glycoprotein in cultured rat PC12 pheochromocytoma cells. Cell 15: 357-365.

McKay, R., M. C. Raff, and L. F. Reichardt, eds. (1981). Monoclonal Antibodies to Neural Antigens. Cold Spring Harbor Rep. Neurosci. 2: 1-282.

Mobley, W. C., A. Schenker, and E. M. Shooter (1976) Char acterization and isolatation of a proteolytically modified nerve growth factor. Biochemistry 15: 5543-5551.

Moscona, A. A. (1976) Cell recognition in embryonic morphogenesis and the problem of neuronal specificities. In Neuronal Recognition, S. H. Barondes, ed., pp. 205 226, Plenum Press, New York. 
O'Farrell, P. H. (1975) High resolution two-dimensional electrophoresis of proteins. J. Biol. Chem. 250: 4007-4021.

Richter-Landsberg, C., L. A. Greene, and M. L. Shelanski (1979) Glycoproteins released by clonal PC12 pheochromocytoma cells and cultured rat sympathetic neurons. In $A b$ stracts of the Seventh Meeting of the International Society for Neurochemistry, Jerusalem, p. 548.

Rohrer, H., and M. Schachner (1980) Surface proteins of cultured mouse cerebellar cells. J. Neurochem. 35: 792-803.

Rudy, B., B. Kirschenbaum, and L. A. Greene (1982) Nerve growth factor-induced increase in saxitoxin binding to rat PC12 pheochromocytoma cells. J. Neurosci. 2: 1405-1411.

Salton, S. R. J. (1983) Nerve growth factor inducible large external (NILE) glycoprotein: Isolation and characterization of a central and peripheral neuronal marker. Ph.D. thesis, New York University.

Salton, S. R. J., C. Richter-Landsberg, L. A. Greene, and M. L. Shelanski (1983) Nerve growth factor-inducible large external (NILE) glycoprotein: Studies of a central and peripheral neuronal marker. J. Neurosci. 3: 441-454.

Sidman, R. L. (1974) Contact interactions among developing mammalian brain cells. In The Cell Surface in Development, A. A. Moscona, ed., pp. 221-253, John Wiley \& Sons, Inc., New York.

Sieghart, W., J. Forn, and P. Greengard (1979) $\mathrm{Ca}^{2+}$ and cyclic AMP regulate phosphorylation of same two membrane-associated proteins specific to nerve tissue. Proc. Natl. Acad. Sci. U. S. A. 76: 2475-2479.

Stallcup, W. B., L. S. Arner, and J. M. Levine (1983) An antiserum against the $\mathrm{PC} 12$ cell line defines cell surface antigens specific for neurons and Schwann cells. J. Neurosci. .3: 53-68.

Waechter, C. J., and W. J. Lennarz (1976) The role of polyprenol-linked sugars in glycoprotein synthesis. Annu. Rev. Biochem. 45: 95-112.

Yankner, B. A., and E. M. Shooter (1979) Nerve growth factor in the nucleus: Interaction with receptors on the nuclear membrane. Proc. Natl. Acad. Sci. U. S. A. 76: 1269-1273.

Yu, M. W., N. Tolson, and G. Guroff (1980) Increased phosphorylation of specific nuclear proleins in superior cervical ganglia and $\mathrm{PC} 12$ in response to nerve growth factor. J. Biol. Chem. 255: 10481-10492. 